ПИТАННЯ ПСИХОЛОГІЧНОГО ВІДБОРУ КАНДИДАТІВ
НА СЛУЖБУ ДО БЮРО ЕКОНОМІЧНОЇ БЕЗПЕКИ УКРАЇНИ

\title{
ISSUES OF PSYCHOLOGICAL SELECTION OF CANDIDATES FOR SERVICE IN THE BUREAU OF ECONOMIC SECURITY OF UKRAINE
}

У статmі розглянуто питання законодавчого забезпечення психологічного відбору кандидатів на службу до Бюро економічної безпеки України. Зокрема, проаналізовано нинішній стан нормативно-правового обгрунтування та регулювання процесів психофізіологічного опитування та психологічного тестування кандидатів на службу; наведено законодавчо закріплені вимоги, що висуваються до кандидатів на службу в Бюро економічної безпеки України; розглянуто приклад першої спроби законодавчого регулювання питань психофрізіологічних досліджень у іншому правоохоронному органі - Державному бюро розслідувань; проведено паралелі та порівняння підходів до законодавчого врегулювання питань застосування поліграфру та здійснення психофрізіологічних досліджень та опитувань; визначено мету психологічного тестування кандидатів на службу, яка полягає у виявленні осіб з ознаками девіантної поведінки, осіб з утрудненою та уповільненою адаптацією, осіб 3 несфрормованою мотивацією; детально розглянуто характеристики, визначення та можливості застосування кожної психологічної якості та характеристики; прогнозовано перспективи та надано рекомендаціі щодо подальшого нормативно-правового врегулювання процесів психологічного тестування, професійно-психологічного відбору та психологічного супроводження діяльності працівників Бюро економічної безпеки України; підкреслено, що для досягнення суспільно значимого результату під час виконання завдань щодо протидії правопорушенням, що посягають на фрункціонування економіки держави, детективи Бюро економічної безпеки України мають право проявляти ситуативно-позитивні фрорми девіантної поведінки; рекомендовано керівництву Бюро економічної безпеки України звернути увагу на запровадження інституту наставництва як важливої складово частини системи професійного відбору та процесу адаптації молодих працівників. у процесі організації діяльності підрозділів Бюро економічної безпеки України керівникам слід враховувати, що успішна мотивація у працівників формується завдяки належній організації роботи, позитивному морально-психологічному клімату, забезпеченню профресійної підготовки, підвищенню кваліфрікації та можливості профресійного і кар'єрного зростання.

Ключові слова: психологічний відбір, психофрізіологічне опитування, поліграфр, психофрізіологічне дослідження, психологічне тес- тування, девіантна поведінка, адаптація, утруднена адаптація, мотивація, несформована мотивація.

The article considers the issues of legislative support of psychological selection of candidates for service in the Bureau of Economic Security of Ukraine. In particular, the current state of legal substantiation and regulation of the processes of psychophysiological examination and psychological testing of candidates for the service is analyzed. There are statutory requirements for candidates for service in the Bureau of Economic Security of Ukraine. An example of the first attempt to legislate psychophysiological research in another law enforcement agency - the State Bureau of Investigation - is considered. Parallels and comparisons of approaches to the legislative regulation of the use of the polygraph are carried out and psychophysiological researches and interrogations are carried out. The purpose of psychological testing of candidates for the service is determined, which is to identify people with signs of deviant behavior, people with difficult and delayed adaptation, and people with unformed motivation. The characteristics, definitions and possibilities of application of each psychological quality and characteristics are considered in detail. Prospects are forecasted and recommendations are given for further legal regulation of the processes of psychological testing, professional and psychological selection and psychological support of the staff of the Bureau of Economic Security of Ukraine. It is emphasized that in order to achieve a socially significant result, performing tasks related to the fight against crimes that encroach on the functioning of the state economy, detectives of the Bureau of Economic Security of Ukraine have the right to demonstrate situationally positive forms of deviant behavior. It is recommended that the management of the Bureau of Economic Security of Ukraine pay attention to the introduction of the institution of mentoring as an important component of the system of professional selection and the process of adaptation of young workers. In the process of organizing the activities of the Bureau of Economic Security of Ukraine, managers should take into account that successful motivation of employees is formed through proper organization of work, positive moral and psychological climate, training, education and professional and career growth opportunities.

Key words: psychological selection, psychophysiological survey, polygraph, psychophysiological research, psychological testing, deviant behavior, adaptation, difficult adaptation, motivation, unformed motivation. ням, що посягають на функціонування економіки держави. Реформування правоохоронних органів нашої країни, зокрема створення Бюро економічної безпеки України, спрямоване на розвиток та зміцнення демократичних засад суспільства, зменшення тиску на платників податків та забезпечення економіч- 
ної безпеки держави. Законодавство передбачає міжнародну співпрацю правоохоронних органів, поступову інтеграцію у світову правоохоронну систему. Зазначені перспективи висувають підвищені вимоги до процесу професійно-психологічного відбору персоналу, вимагають підвищення якості роботи з кадрами та використання кращого світового досвіду у психологічному забезпеченні сфери економічної безпеки.

Орієнтація суспільства на пріоритети загальнолюдських цінностей вимагає у Бюро економічної безпеки України (далі Бюро) забезпечення прозорості діяльності та суспільного контролю. Задля цього законодавець передбачив створення ради громадського контролю при Бюро, необхідність для Бюро регулярного інформування суспільства про свою діяльність, установив обов'язковий щорічний звіт директора Бюро перед Верховною Радою України, Кабінетом Міністрів України про діяльність Бюро за попередній рік.

На сучасному етапі, у процесі створення та комплектування Бюро економічної безпеки України, пріоритетного значення набувають завдання забезпечення підрозділів Бюро професійно та психологічно придатними й високопрофесійними працівниками.

Законодавче забезпечення певних аспектів проблеми професійного психологічного відбору кандидатів на службу отримало своє відображення у Законі України «Про Бюро економічної безпеки України». Норми Закону закріплюють основні вимоги до кандидата на службу, регламентуючи, зокрема, що на службу приймаються на конкурсній основі в добровільному порядку громадяни України, які здатні за своїми особистими, діловими та моральними якостями, віком, освітнім та професійним рівнями, а також станом здоров'я ефективно виконувати відповідні службові обов'язки. Крім того, кандидати на службу за їх згодою проходять психофізіологічне опитування та обов'язкове психологічне тестування.

Постановка завдання. Метою статті $€$ розгляд питань законодавчого забезпечення психологічного відбору кандидатів на службу до Бюро економічної безпеки України.

Виклад основного матеріалу дослідження. Законом України «Про Бюро економічної безпеки України» від 28 січня 2021 року № 1150-IX (далі - Закон № 1150-IX) визначено поняття детектива Бюро економічної безпеки України (далі - Бюро). Детектив Бюро - службова особа, уповноважена в межах компетенції, визначеної Законом України «Про оперативно-розшукову діяльність» (далі - Закон № 2135-XII) та Кримінальним процесуальним кодексом України [1].
Частиною 1 статті 24 Закону № 1150-IX передбачено, що кандидати на посаду в Бюро економічної безпеки України, що передбачають спеціальні звання Бюро економічної безпеки України, за їх згодою проходять психофізіологічне опитування із застосуванням поліграфа [1].

В абзаці 2 частини 1 статті 24 Закону № 1150-ІХ визначено, у чому полягає психофізіологічне опитування. Психофізіологічне опитування із застосуванням поліграфа полягає у нешкідливому для життя й здоров'я людини опитуванні з використанням поліграфа - багатоканального пристрою, призначеного для реєстрації та запису в реальному часі показників емоційної напруги особи, що виникають як реакція на інформацію у вигляді слів, зображень тощо [1].

Необхідно зазначити, що це не перша спроба законодавчого врегулювання питання використання поліграфа у сфері професійного відбору кандидатів на посаду. У Законі України «Про Державне бюро розслідувань» питанням проведення психофізіологічного дослідження із застосуванням поліграфа присвячено статтю 26. Нормами цієї статті регламентовано проведення поліграфічного дослідження кандидатів до вступу на службу до Державного бюро розслідувань, а також працівників ДБР не рідше одного разу на рік під час проходження служби [2].

Нормами Закону № 1150-IX не регламентовано періодичність поліграфічних досліджень працівників Бюро економічної безпеки України, натомість законодавець покладає на Директора Бюро економічної безпеки України повноваження щодо прийняття рішення про необхідність проведення психофізіологічного опитування діючих працівників із застосуванням поліграфа.

Закон № 1150-ІХ вперше на законодавчому рівні закріплює необхідність психологічного тестування кандидатів на посади, що передбачають спеціальні звання Бюро економічної безпеки України, тобто на законодавчому рівні визначаються психологічні засади професійного відбору кандидатів. Законодавець передбачив, що психологічне тестування має проводитися задля виявлення серед кандидатів осіб з ознаками девіантної поведінки; з утрудненою або уповільненою адаптацією; з несформованою мотивацією [1].

Розглянемо законодавчо закріплені вимоги до кандидатів на посади в Бюро більш детально.

\section{Девіантна поведінка.}

У Законі № 1150-IX девіантна поведінка визначається як форма особистої поведінки кандидата, що суперечить загальноприйнятим моральним або правовим (дисциплінарним) нормам. 
Термін «девіантна поведінка» походить від латинського deviatio («відхилення»). Отже, людина з девіантною поведінкою поводиться не так, як усі, її поведінка відрізняється від звичної, прийнятої для оточення [3, с. 15].

Нині існують різні наукові підходи до класифікації та типологізації девіантної поведінки. Психологи стверджують, що відхилення від норми можуть бути як негативними, так і позитивними. У разі позитивних девіацій йдеться про нестандартну особистість, для якої характерні оригінальні, творчі ідеї та креативні, нестандартні вчинки, дії.

У межах психологічного підходу науковці виокремлюють три такі основні групи поведінкових девіацій:

- негативні (наприклад, вживання наркотиків);

- позитивні (наприклад, творчість, креативність);

- нейтральні (наприклад, жебрацтво) [3, с. 23].

У межах кримінологічного підходу вітчизняний науковець С. Корецький запропонував три такі підтипи девіантної особистості [4, с. 17]:

- ситуативно-девіантний підтип - підтип особи, для системи цінностей якої характерна наявність установок на вчинення девіантних дій тільки за умов надзвичайно складних життєвих ситуацій, що відверто спонукають до вчинення саме таких дій;

- стійкий девіантний підтип - підтип особи, для системи цінностей якої характерна наявність життєвих установок, які обумовлюють існування навколо особи соціального оточення, в якому відхилення від нормативних систем, не санкціонованих державою, але загальновизнаних суспільством, визнаються нормою поведінки (інституалізація девіації);

- послідовно девіантний підтип - підтип особи, для системи цінностей якої характерні установки на свідоме формування соціального оточення, для якого девіація $є$ нормою життя.

На нашу думку, зрозумілим та цілком очевидним $є$ той факт, що для кандидатів на посаду в Бюро неприйнятними $€$ негативні та нейтральні девіації у межах психологічного підходу. Водночас ознаки позитивної девіації у кандидата на службу мають оцінюватися схвально. На ці аспекти проблеми необхідно звернути увагу під час підготовки та ухвалення відомчих нормативно-правових актів якими буде регламентований порядок професійного відбору кандидатів та проходження ними психологічного тестування.

Крім того, з огляду на те, що детектив Бюро уповноважений здійснювати оперативно-розшукову діяльність (пункт 2 частини 1 статті 2 Закону № 1150-IX), а до працівників Бюро належать особи, які є гласними та негласними штатними працівниками (частина 1 статті 19
Закону № 1150-ІХ), виникає закономірний висновок щодо службової (оперативної) необхідності використання працівниками ситуативно-девіантного типу поведінки, наприклад, у ситуаціях проведення контрольованої поставки та контрольованої і оперативної закупки товарів, предметів та речовин (пункт 2 частини 1 статті 8 Закону № 2135-XII), негласного виявлення та фіксування слідів тяжкого або особливо тяжкого злочину, документів та інших предметів, що можуть бути доказами підготовки або вчинення такого злочину, у тому числі шляхом проникнення та обстеження публічно недоступних місць (пункт 7 частини 1 статті 8 Закону № 2135-XII), під час здійснення спостереження за особою, річчю або місцем, а також аудіо-, відеоконтроля місця (пункт 11 частини 1 статті 8 Закону № 2135-XII) тощо [5].

У зазначених випадках детектив Бюро свідомо проявлятиме форми девіантної поведінки, однак ці форми $€$ необхідними для досягнення суспільно значимого результату, отже, такі форми девіацій $€$ позитивними та ситуативними. Таким чином, можемо констатувати, що для досягнення суспільно значимого результату під час виконання завдань щодо протидії правопорушенням, що посягають на функціонування економіки держави, детективи Бюро мають право проявляти ситуативно-позитивні форми девіантної поведінки.

\section{Адаптація.}

Адаптація (від лат. adaptation - «пристосування») - це зміни, що супроводжують на рівні психічної регуляції процес активного пристосування індивіда до нових умов життєдіяльності. Адаптація працівника - це процес пристосування індивіда до робочого місця й трудового колективу [6; 7].

Оскількиадаптація -цепроцес, то виявлення осіб з утрудненою або уповільненою адаптацією серед кандидатів на посади виключно шляхом психологічного тестування - це надзвичайно складне завдання. Тестові методики, що дають змогу оцінити процес адаптації ще до початку самої адаптації, не зможуть дати релевантних та валідних результатів, а, навпаки, можуть відсіяти тих кандидатів, які б змогли показати високі результати у професійній діяльності. Наприклад, деякі психологічні тестові методики, що покликані визначити рівень адаптації, фактично визначають комунікативні якості особистості, припускаючи, що високий рівень розвитку комунікативних якостей прямо корелює з рівнем адаптації. Таким чином, особа, яка за своїм темпераментом $€$ інтровертом, продемонструє невисокий рівень розвитку комунікативних якостей та не буде зарахована на службу, у реальному житті може виявитися супераналітиком, отже, в разі зарахування на службу такий кандидат 
зміг би продемонструвати свої найкращі якості та чудово адаптувався б до вимог та умов професійної діяльності.

Не слід забувати, що адаптація відбувається на робочому місці. Таким чином, працівник Бюро, потрапивши на робоче місце, повинен пристосуватися до свого робочого місця та трудового колективу. Пристосування до робочого місця - це засвоєння вимог професії до працівника, а пристосування до трудового колективу - це засвоєння традицій, норм, правил та розуміння структури організації.

Необхідно враховувати, що для прискорення процесу адаптації, надання допомоги новачкам у освоєнні професії, передачі досвіду традиційно у правоохоронних органах України використовувався інститут наставництва.

На нашу думку, керівництво Бюро економічної безпеки України має звернути увагу на запровадження інституту наставництва як важливої складової частини системи професійного відбору та процесу адаптації молодих працівників.

\section{Мотивація.}

Мотивація (від лат. movere - «спонукання до дії») - динамічний процес фізіологічного та психологічного аспектів, керуючий поведінкою людини, який визначає її спрямованість, організованість, активність та стійкість; здатність людини діяльнісно задовольняти свої потреби.

Поняття мотивації вживається у таких двох значеннях:

- як система факторів, що викликають активність організму та визначають спрямованість поведінки людини; до них належать потреби, мотиви, наміри, цілі, інтереси, прагнення;

- як характеристика процесу, що забезпечує поведінкову активність на певному рівні, іншими словами, мотивування [8, с. 38].

Найбільш дієвим мотивом поведінки людини $\epsilon$ усвідомлення індивідом своїх потреб. А. Маслоу запропонував теорію ієрархії потреб, відповідно до якої усі потреби розділив на п'ять таких основних категорій: секс);

- фізіологічні потреби (їжа, вода, сон,

- потреби безпеки та захисту;

- соціальні потреби;

- потреби у повазі;

- потреби самовираження [9].

Проведене авторами опитування працівників правоохоронних органів, що виконують функції, споріднені з функціями Бюро, дало змогу виділити такі найбільш значимі мотиви, що спонукають до бажання працювати у вибраній професії:

- можливість реалізувати свої здібності та отримати повагу суспільства;
- гарний колектив та перспектива кар'єрного росту;

- гарантії соціального захисту;

- гідна заробітна плата та пенсійне забезпечення;

- гарантії процесуальної самостійності та незалежності;

- мотиви творчої діяльності.

Таким чином, у процесі організації діяльності підрозділів Бюро економічної безпеки України керівникам слід враховувати, що успішна мотивація у працівників формується завдяки належній організації роботи, позитивному морально-психологічному клімату, забезпеченню професійної підготовки, підвищенню кваліфікації та можливості професійного і кар'єрного зростання.

Висновки з проведеного дослідження. Таким чином, нами започатковано розгляд проблеми нормативно-правового регулювання психологічного відбору кандидатів на службу до Бюро економічної безпеки України. Встановлено, що засадничі норми та напрями подальшого розвитку питань професійного психологічного відбору та психологічного супроводження закладені у Законі України «Про Бюро економічної безпеки України». Крім того, Бюро економічної безпеки України наділене повноваженнями створювати та затверджувати відповідні положення відомчими нормативно-правовими актами.

\section{ЛІТЕРАТУРА:}

1. Про Бюро економічної безпеки України : Закон України від 28 січня 2021 року № 1150-ІХ / Верховна Рада України. URL: https://zakon.rada.gov.ua/laws/ show/1150-21\#Text (дата звернення: 24.04.2021).

2. Про Державне бюро розслідувань : Закон України від 12 листопада 2015 року № 794-VIII / Верховна Рада України. URL: https://zakon.rada.gov.ua/ laws/show/794-19\#Text (дата звернення: 22.04.2021).

3. Максимова Н. Психологія девіантної поведінки. Київ, 2011. 520 с.

4. Корецький С. Кримінологічна характеристика девіантної поведінки неповнолітніх : автореф. дис. ... канд. юрид. наук : спец. 12.00.08. Київ, 2003. 22 с.

5. Про оперативно-розшукову діяльність : Закон України від 18 лютого 1992 року № 2135-XII / Верховна Рада України. URL: https://zakon.rada.gov.ua/ laws/show/2135-12\#top (дата звернення: 22.04.2021).

6. Майдіков Ю., Корсун С. Нервова система і психічна діяльність людини : навчальний посібник. Київ, 2007. 280 с.

7. Корсун С. Методичні рекомендації по профресійному психологічному відбору працівників оперативних підрозділів податкової міліції. Київ, 2007. 18 с.

8. Дмитренко Г., Шарапатова Е., Максименко Т. Мотивация и оценка персонала : учебное пособие. Киев, 2002. 248 с.

9. Maslow A.H. A Theory of Human Motivation. Psychological Review. 1943. № 50. P. 370-396. 